\title{
CONTROLLABLE RESONANT TYPE CONVERTER DEVELOPMENT FOR CAPACITOR CHARGING LOADS
}

\author{
I.V. Volkov*, S.V. Podolnyi \\ Institute of Electrodynamics National Academy of Sciences of Ukraine, \\ pr. Peremohy, 56, Kyiv, 03057, Ukraine. $\quad$ E-mail: dgp@ukr.net
}

The paper investigates various controlling options for the selected resonant converter topology, which is optimized for capacitor charging systems. Several of the controlling algorithms were studied in depth, and one of them was practically verified. There are two major advantages about the system: full/partial soft-switching mode what allows to use higher switching without the system efficiency drop; controllable energy flow from the input to the output, without any additional sophisticated parts. References 6 , figures 9 .

Key words: resonant converter, capacitor charging systems, soft-switching.

Introduction. Capacitor charging systems are widely used for various industrial, special, domestic, science experiments electrical and power electronic applications, like pulse welding, laser technic, magnetoimpulse processing of metals, volume electro-erosion processing, etc. [3]. The major operational condition for such system types is an economic charge of the storage capacitor according to some specific time-domain law, and optimal interrelations between processes in the charging circuit and the power source (especially if it's autonomous one) $[2,3]$.

There are three main methods known for the storage capacitor charging: from constant voltage type source, from constant current type source and from constant power type source $[4,6]$. The first one has low efficiency - below $50 \%$ due to the restricting input current requirement with a resistor. In the case of using a current limiting inductor, its energy capacity (sizes and price accordingly) is relatively big, and contributes to more than quarter to the device energy capacity [3].

The main drawback of the second type - the maximum power of the power source two times exceeds the average power per cycle, required for the capacitor full charging. The constant power case has the disadvantage of increased dynamical energy losses in its semiconductor devices, which create such a mode at the first place.

There are numerous schematic methods exist for overcoming those disadvantages in each particular case, and in this article we use quasi-separated schematic of two separate resonant tanks (Fig. 1) to facilitate hard-switching energy losses and EMI-effects of conventional power converter equipment and improve switching conditions for the semiconductors switches. For these purposes we utilize in the converter a transitional "small" capacitor $C_{0}$, that during the charging cycle of the "big" output capacitor $C_{\text {out }} \gg C_{0}$ repeatedly transfers small portions of energy ("quants") until the system is fully charged.

In this article, we propose and compare possible algorithms for the converter switches, which would provide optimal energy transfer with minimal dynamical losses in the transistors switches.

All the switches here are one directional. Several theoretical algorithms can be used for obtaining different types of the converter behaviours. For this particular reason the Fig. 1 schematic includes $\mathrm{K}_{21}$ as a controllable element, though in some cases this one can be substituted with a diode. We don't consider static losses at the beginning (Fig. 1 doesn't contain resistive elements in order to simplify functional possibilities of the device analytically).

The first resonant tank. This circuit works during the switch $\mathrm{K}_{1}$ conductive state, and closed $\mathrm{K}_{2}$ respectively. It has three elements $\left\{\mathrm{U}_{\mathrm{in}}, \mathrm{L}_{0}, \mathrm{C}_{0}\right\}$ with two possible initial states on the $C_{0}$. The transient processes are described by well known equations [1]

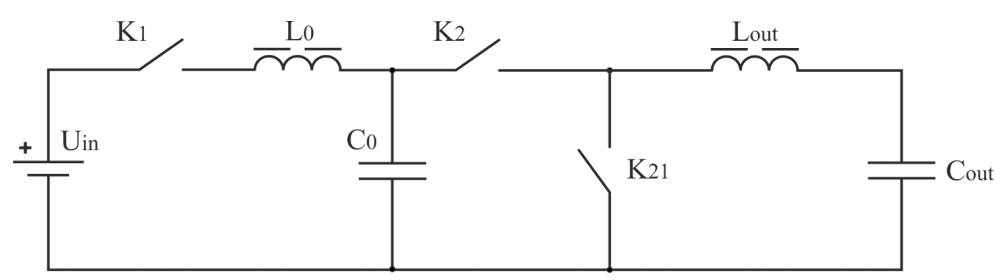

Fig. 1

(C) Volkov I.V., Podolnyi S.V., 2017

ORCID ID: *http://orcid.org/0000-0002-0696-0382 


$$
L_{0} \frac{d^{2} i}{d t^{2}}+\frac{1}{C_{0}} i=0 \rightarrow i(t)=\frac{U_{i n}}{L_{0} \omega} \sin (\omega t),
$$

where $Z=\sqrt{L_{0} / C_{0}}$ is the wave impedance; $\omega=1 / \sqrt{L_{0} C_{0}}$ is the circular frequency.

The voltage $C_{0}$

$$
u(t)=\frac{1}{C_{0}} \int i(t) \cdot d t=\frac{1}{C_{0}} \int \frac{U_{\text {in }}}{L_{0} \omega} \sin (\omega t) d t=U_{\text {in }}\left\{-\left.\cos (\omega t)\right|_{0} ^{t}\right\} \rightarrow u(t)=U_{\text {in }}[1-\cos (\omega t)] .
$$

In the case of considering the transient half-cycle, i.e. $t=\pi / \omega, U_{C 0}=2 U_{i n}$.

The doubled voltage require two additional conditions: the active resistance is negligible; zero initial condition $U\left(C_{0}\right)=0$.

Let's consider the case $U\left(C_{0}\right)=\widetilde{U}_{C 0}$, then (1) transforms to the following

$$
i(t)=\frac{U_{i n}-U_{C 0}}{Z} \sin (\omega t) \text {, }
$$

and the voltage $C_{0}$

$$
u(t)=\widetilde{U}_{C 0}+\frac{1}{C_{0}} \int i(t) \cdot d t=\widetilde{U}_{C 0}+\left(U_{i n}-\widetilde{U}_{C 0}\right)[1-\cos (\omega t)] .
$$

As can be seen from (4), at the moment $\mathrm{t}=\pi / \omega$

$$
U_{C 0}=\widetilde{U}_{C 0}+2\left(U_{\text {in }}-\widetilde{U}_{C 0}\right)=2 U_{\text {in }} \pm\left|\widetilde{U}_{C 0}\right| \text {. }
$$

That means the initial condition can both increase or decrease the transferring energy of the converter per working cycle.

The second resonant tank. The circuit include three basic elements with its initial conditions. Fig. 2 bellow shows the above mentioned in Laplace domain. The operational circuit components are: the "large"

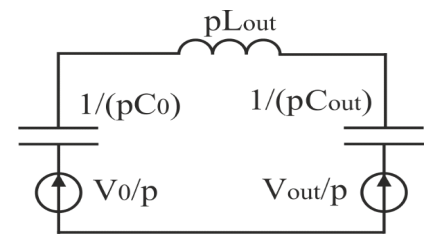

Fig. 2 output capacitor $C_{\text {out }}>>C_{0}$, the dosing "small" capacitor $C_{0}$ with initial condition $V_{0}=U_{C 0}$ and $V_{\text {out }}$ - variable part of the output capacitor voltage at $\mathrm{n}^{\text {th }}$ step of charging. Normally, $L_{\text {out }}$ initial current $I_{\text {Lout }}(0)=0$. The operational current $I(p)$

$$
I(p)=\frac{N(p)}{M(p)}=\frac{V_{0} / p-V_{\text {out }} / p}{1 / p C_{0}+1 / p C_{\text {out }}+p L_{\text {out }}}=\frac{V_{0}-V_{\text {out }}}{1 / C_{0}+1 / C_{\text {out }}+p^{2} L_{\text {out }}} .
$$

theorem

Inverse Laplace-transformation for $I(p)$ according to the decomposition

$$
i(t)=\sum_{k=1}^{2} \frac{N\left(p_{k}\right)}{\frac{d M}{d p}\left(p_{k}\right)}=\frac{V_{0}-V_{\text {out }}}{2 j \omega L_{\text {out }}} e^{j \omega t}-\frac{V_{0}-V_{\text {out }}}{2 j \omega L_{\text {out }}} e^{-j \omega t},
$$

where $p_{k}$ is the roots of the $M(p)$ polynomial. Since $e^{-j \omega t}-e^{j \omega t}=-2 j \sin (\omega t)$,

$$
i(t)=\frac{V_{0}-V_{\text {out }}}{\omega L_{\text {out }}} \sin (\omega t)=\frac{V_{0}-V_{\text {out }}}{Z} \sin (\omega t) .
$$

$C_{\text {out }}$ voltage

$$
\begin{gathered}
u_{\text {out }}(t)=V_{\text {out }}+\frac{1}{C_{\text {out }}} \int i(t) d t=V_{\text {out }}+\frac{1}{C_{\text {out }}} \int_{0}^{t} \frac{V_{0}-V_{\text {out }}}{Z} \sin (\omega t) d t \rightarrow \\
u_{\text {out }}(t)=V_{\text {out }}+\frac{V_{0}-V_{\text {out }}}{\omega C_{\text {out }} Z}(1-\cos (\omega t)) .
\end{gathered}
$$

Note $\omega C_{\text {out }}=C_{\text {out }} \sqrt{L_{\text {out }} / C_{\Sigma}} \cdot 1 / \sqrt{L_{\text {out }} C_{\Sigma}}=C_{\text {out }} / C_{\Sigma}, C_{\Sigma}=C_{0} C_{\text {out }} /\left(C_{0}+C_{\text {out }}\right)$, hence

$$
u_{\text {out }}(t)=V_{\text {out }}+\frac{C_{\Sigma}}{C_{\text {out }}}\left(V_{0}-V_{\text {out }}\right)(1-\cos (\omega t)) \text {. }
$$

Let $\alpha_{C}=C_{\Sigma} / C_{\text {out }}$, then $\quad u_{\text {out }}(t)=V_{\text {out }}+\alpha_{C}\left(V_{0}-V_{\text {out }}\right)(1-\cos (\omega t))$.

Since $C_{\Sigma} \cong C_{0} \rightarrow \alpha_{C}<<1$. 
Similarly capacitor $C_{0}$ voltage $\quad u_{C 0}(t)=V_{0}-\frac{1}{C_{0}} \int i \cdot d t=V_{0}-C_{\Sigma} \frac{V_{0}-V_{\text {out }}}{C_{0}}(1-\cos (\omega t))$.

Let $\beta_{C}=C_{\Sigma} / C_{0}$, then $\quad u_{C 0}(t)=V_{0}-\beta_{c}\left(V_{0}-V_{\text {out }}\right)(1-\cos (\omega t))$.

Due to $C_{\Sigma} \cong C_{0} \rightarrow \beta_{C} \cong 1$.

At the moment $\omega t=\pi$, or the full half-cycle, the residual voltage of the dosing capacitor

$$
u_{\text {res }}=V_{0}-2 \beta_{c}\left(V_{0}-V_{\text {out }}\right) \text {. }
$$

The dosing capacitor is fully discharged $u_{\text {res }}=0$ only in one case

$$
\frac{V_{0}}{V_{0}-V_{0 u t}}=2 \frac{C_{\Sigma}}{C_{\text {out }}}
$$

or if $C_{\text {out }} \gg>C_{0}$, then $V_{\text {out }} \cong 0.5 V_{0}$.

For all other cases, it will have positive or negative residual voltage.

Generally speaking, in some real cases we could encounter not zero initial condition for the inductor current $I_{\text {Lout }}(0) \neq 0 \neq I_{0}$.

By rewriting (6) implying this additional condition

$$
I(p)=\frac{V_{0} / p-V_{\text {out }} / p+L_{\text {out }} I_{0}}{1 / p C_{0}+1 / p C_{\text {out }}+p L_{\text {out }}}=\frac{V_{0}-V_{\text {out }}+p L_{\text {out }} I_{0}}{1 / C_{0}+1 / C_{\text {out }}+p^{2} L_{\text {out }}} .
$$

The inverse Laplace-transformation for the $I(p)$

$$
i(t)=\left(j \frac{V_{0}-V_{\text {out }}}{2 \omega L_{\text {out }}}+\frac{I_{0}}{2 \omega}\right)\left(e^{-j \omega t}-e^{j \omega t}\right)=I_{m} \sin (\omega t+\varphi),
$$

where $\widetilde{I}_{m}=\sqrt{I_{0}^{2}+\left(\frac{V_{0}-V_{\text {out }}}{Z}\right)^{2}}=\frac{\sqrt{I_{0}^{2} Z^{2}+\left(V_{0}-V_{\text {out }}\right)^{2}}}{Z}=\frac{\widetilde{U}_{m}}{Z}$,

$$
\varphi=\frac{\pi}{2}-\operatorname{arctg}\left[\frac{V_{0}-V_{\text {out }}}{Z I_{0}}\right]=\frac{\pi}{2}-\arcsin \left[\frac{Z I_{0}}{\sqrt{I_{0}^{2} Z^{2}+\left(V_{0}-V_{\text {out }}\right)^{2}}}\right] .
$$

Respectively $C_{\text {out }}$ voltage

$$
u_{\text {out }}(t)=V_{L}+\frac{1}{C_{\text {out }}} \int_{0}^{t} I_{m} \sin (\omega t+\varphi)=V_{L}+\alpha_{C} \widetilde{I}_{m} Z[\cos (\varphi)-\cos (\omega t+\varphi)] .
$$

And $C_{0}$ voltage $\quad u_{C 0}(t)=V_{0}-\frac{1}{C_{\text {out }}} \int_{0}^{t} I_{m} \sin (\omega t+\varphi)=V_{0}-\chi_{C} \widetilde{I}_{m} Z[\cos (\varphi)-\cos (\omega t+\varphi)]$.

The equation (9) shows that there are two variables for $u_{\text {out }}(t)$ : $V_{0}$ and $\mathrm{t}$ which can be controlled dynamically. Both the tanks can be adjusted to influence these parameters to a certain degree. Consequently, the full spectra of possible controlling algorithms, for the "large" capacitor charging, are predetermined by these two variables.

Controlling algorithms. Let's consider some of them in more details.

1.1: $V_{0}, t$ are not regulated.

In this case, both the input and the output resonant tanks work under pure soft-switching conditions, so dynamic losses are zero. The residual voltage $u_{\text {res }}$ of the dosing capacitor rapidly increases on each charging cycle, and the magnitude of the input current respectively, until the following condition $V_{\text {out }}=U_{\text {in }}$ takes place. After that knee point $V_{\text {out }}>U_{\text {in }}$, and the input current $I_{\text {in }}$ decreases by the same rate, i.e. it's symmetrical respectively to the knee.

Theoretical charging limit for the case approaches doubled input voltage, or $V_{\text {out }} \rightarrow 2 \cdot U_{\text {in }}$.

The case has a significant drawback, namely very high growing rate of the input current, which for the practical schemes should almost always be limited to an upper maximum value. 
Let's consider the example $U_{\text {in }}=310 \mathrm{~V}, Z=50 \mathrm{Ohm}, \alpha_{\mathrm{C}}=5 \mathrm{e}-3$. Then the charging dynamic is illustrated bellow (Fig. 3). The voltage Uout here is shown on a
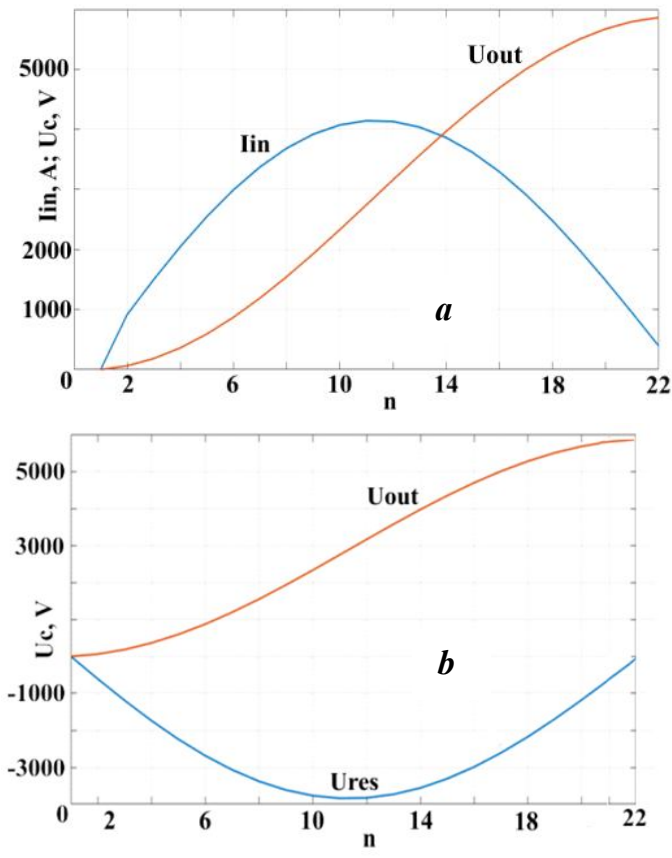

Fig. 3 scale 10:1.

The output voltage grows until the residual voltage on the dosing capacitor $u_{\text {res }} \leq 0$ (Fig. 3, a). If $u_{\text {res }}>0$ then the output does not get any new energy portion due to the circuit conducts only in one direction, otherwise it would discharge backwardly, $U_{C 0}<U_{C L}$ (Fig. 3, $b$ ).

1.2: $V_{0}$ is regulated in the first link.

It can be shown that that the input link equations for its current and the dosing capacitor voltage, under all non-zero initial conditions, are similar to (14), (15)

$$
\begin{gathered}
\left\{\begin{array}{c}
i(t)=I_{m} \sin (\omega t+\varphi), \\
u_{C 0}(t)=V_{0}+I_{m} Z[\cos (\varphi)-\cos (\omega t+\varphi)],
\end{array}\right. \\
I_{m}=\frac{\sqrt{I_{0}^{2} Z^{2}+\left(V_{0}-V_{\text {out }}\right)^{2}}}{Z}, \quad \varphi=\frac{\pi}{2}-\operatorname{arctg}\left[\frac{V_{0}-V_{\text {out }}}{Z I_{0}}\right] .
\end{gathered}
$$

According to (17) $V_{0}$ can be regulated with the getting away from the full soft-switching concept and introducing beforehand commutation of the input switch timing $t_{o n}$ or the input angle $\alpha_{o n}$, i.e. $t_{o n}<\pi / \omega$. Here we make a deal with the trade-off of somewhat decreased scheme overall efficiency for

the ability to limit the input current.

Taking into account the aforesaid condition for $t_{o n} / \alpha_{o n}$, let's rewrite (17) as follow

$$
\left\{\begin{array} { c } 
{ I _ { m } \operatorname { s i n } ( \omega t + \varphi ) \leq I _ { \operatorname { m a x } } } \\
{ V _ { 0 } + I _ { m } Z [ \operatorname { c o s } ( \varphi ) - \operatorname { c o s } ( \omega t + \varphi ) ] \leq U _ { \operatorname { m a x } } }
\end{array} \rightarrow \left\{\begin{array}{c}
\alpha_{o n} \leq \arcsin \left[I_{\max } / I_{m}\right] \\
\alpha_{o n} \geq \arccos \left[\cos (\varphi)-\frac{U_{\max }-V_{0}}{I_{m} Z}\right]-\varphi,
\end{array}\right.\right.
$$

where $U_{\max }$ is the dosing capacitor maximum voltage; $I_{\max }$ is the maximum magnitude of the input current for all charging cycles.

The second equation of (18) adds limitation to the maximum residual voltage

$$
\left|\cos (\varphi)-\frac{U_{\max }-u_{\text {res }}}{I_{\max } Z}\right| \leq 1
$$

Let's consider the example, where $U_{\max }=2 U_{i n}$, besides there's a complyance to all other restrictions. It should be noted, that for this type of regulation we have to include additional energy return circuit for the inductor energy not to be wasted while the switch commutation occurs, otherwise the input circuit will have low efficiency with high EMC-noise radiation.

By assuming the foresaid true, our system is simplified and before each new cycle $I_{0}=0$, hence

$$
I_{m}==\frac{\sqrt{I_{0}^{2} Z^{2}+\left(V_{0}-V_{\text {out }}\right)^{2}}}{Z}=\frac{U_{\text {in }}-V_{0}}{Z} .
$$

Let's consider the second controlling algorithm to the same parameters that we mentioned in the previous case. The corresponding model output capacitor theoretical limit, under selected $U_{\max }=2 U_{\text {in }}$ condition, approaches $U_{\text {out }} \rightarrow 1.2 U_{\text {in }}$. The output resonant tank works in the soft-switching mode all the time. Total amount of charging cycles -45 , what's notably longer than the previous case (Fig. 4, a). The result is obvious, since the system pumps less energy per cycle on average.

The upper limit $U_{\max }$ defines the maximum residual voltage of $C_{0}$, which in its turn sets the input current magnitude for the next charging
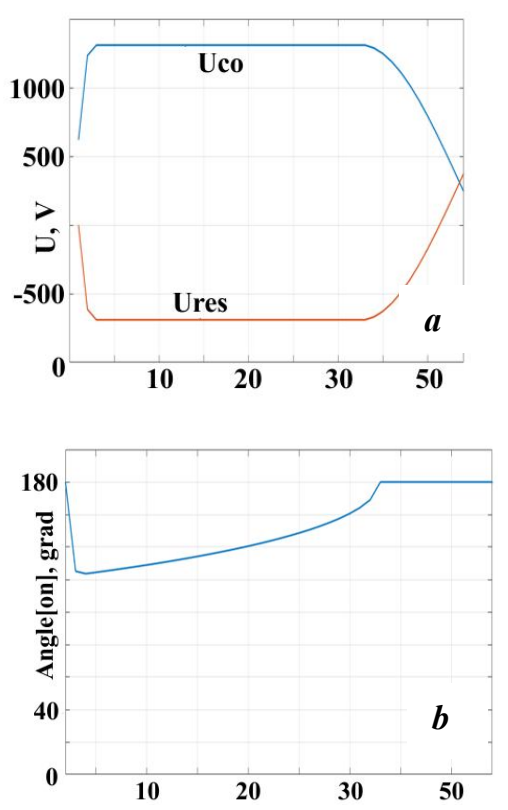

Fig. 4 
cycle. Fig. 4, $b$ illustrates $t_{o n} / \alpha_{o n}$ behaviour, as was mentioned before if $\alpha_{o n} \neq \pi$ then additional switching losses exist; they have the decreasing tendency over time. As can be seen after 32 cycles the systems works in full soft-switching mode, what corresponds to the following condition $U_{\text {out }}=U_{\text {in }}$.

$\underline{\text { 1.3: }} I_{0}$ is regulated in the first link.

In the previous case we took $U_{\max }$ as the main limitation from (18). Alternatively, $I_{m} \sin (\omega t+\varphi) \leq I_{\max }$ can be selected for the same purpose. Similary to the case 1.2 an additional energy return circuit for the inductor is needed.

Expression (20) gives us the following limitation on the peak current

$$
I_{m} \leq \frac{1}{Z}\left(U_{\text {in }}-V_{0}\right) \rightarrow U_{\text {in }}>U_{\text {in }(\min )} .
$$

Expression (21) shows that $I_{m} \& U_{\max } \& u_{\text {res }}$ eventually are the same thing from the selected limitation point of view, linearly dependant on each other; i.e. we could select any limitation here suitable to a specific task. The overall process does not change.

2.1: $u_{\text {out }}$ limitation in the second tank.

As shown on Fig. 1, by introducing $\mathrm{K}_{21}$ switching element, the output circuit gains the ability to limit the residual voltage/input current by way of isolating $C_{0}$ from the superfluous recharging current at an appropriate moment of time.
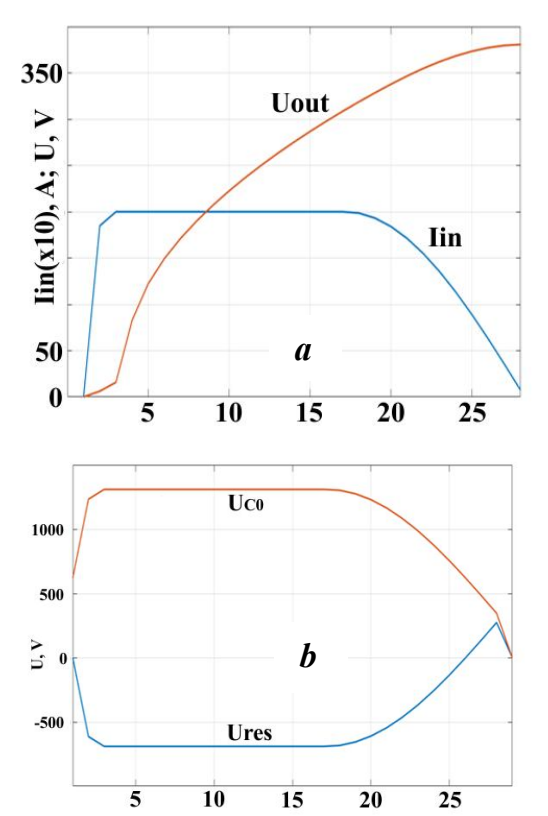

Fig. 5

The controlling algorithm for the case works in three stages: 1) $C_{0}$ charging from the input; 2) $C_{0}$ discharging with the residual voltage limiting; 3) waiting until the $L_{\text {out }}$ magnetic energy will be fully transferred to the output capacitor.

For such a scenario the total charging-discharging cumulative time $T_{C}=t_{1}+t_{2}+t_{3}$ varies, due to $L_{\text {out }}$ initial condition isn't constant, besides the residual magnetic energy transferring isn't fast process, $f_{\text {Lout, Cout }} \gg f_{\text {Lout }, C_{0}}$, and at the beginning the situation when $t_{3}>t_{1}+t_{2}$ rather possible. Consequently, the input impulses duty-cycle is not uniform, changing from some maximum to its minimum $-50 \%$.

Even though the charging process takes 28 cycles (Fig. 5), the value $\sum_{27} T_{C}$ is bigger than for the previous case with almost 50 cycles. The output voltage approaches $U_{\text {out }} \rightarrow 1.2 U_{\text {in }}$.

The output switch works in both modes, namely it has hardswitching closing for the first seventeen cycles, and the full softswitching mode afterwards. The peak of residual magnetic energy $I_{\text {res }}$ is defined by both $I_{0} / U_{\max } / u_{\text {res }}$ value and the system parameters. Fig. 6 shows the same process for the input/output currents dosing in time domain.

The simplest practical implementation for the case is using a diode as the $\mathrm{K}_{21}$ switch. An ideal diode will be automatically turned on when the dosing capacitor voltage

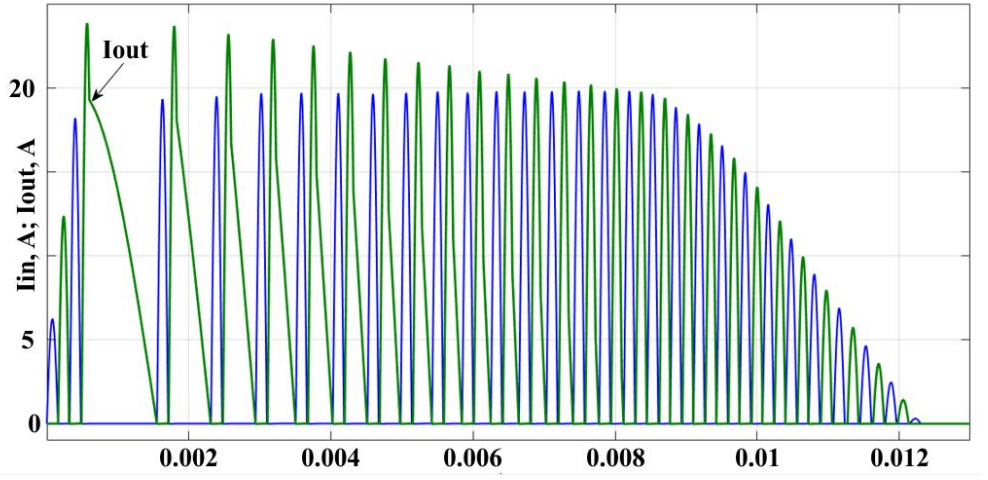

Fig. 6 reaches zero, therefore the residual voltage also stay zero and the system works in full soft-switching mode for the whole time. Besides the approach simplifies the controlling system implementation. If the full charging time is a critical parameter - this will a drawback, because of the limitation on the maximum transferred energy per cycle.

The diode switching time is volatile, can be found as follow

$$
U_{C 0}=V_{0}-\beta_{C}\left(V_{0}-V_{L}\right)(1-\cos (\omega t))=0 \rightarrow
$$




$$
\omega t=\arccos \left[1-\frac{V_{0}}{\beta_{C}\left(V_{0}-V_{L}\right)}\right] .
$$

Fig. 7 shows the dynamic for the case of using a diode. After the $50^{\text {th }}$ cycle the dosing capacitor has residual positive voltage which respectively decrease input current until the final point. The process last about two times longer in comparing to the controllable $\mathrm{K}_{21}$.

There is a possibility to simplify further the controlling algorithm by making the duty cycle constant, however for the price - the current at the beginning will have higher magnitude (Fig. 8).

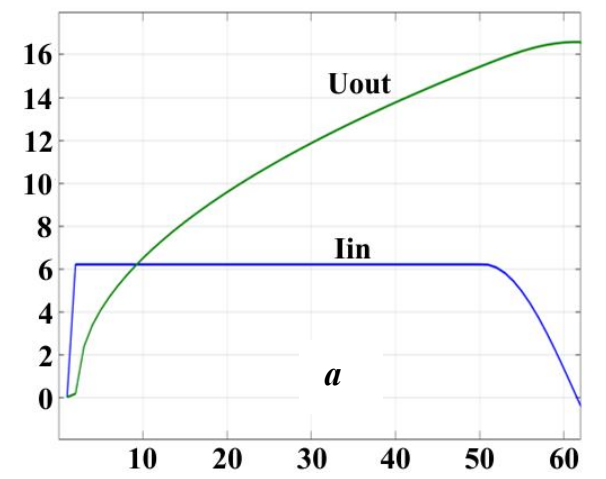

The average pumping energy her is higher, hence the charging process is a bit faster. Special precautions should be taken for the diode selection, otherwise its life-cycle could be tangibly shortened.

This variant was investigated experimentally. On estimation level, we confirmed dynamical characteristics of the system, what is shown on the following pictures Fig. 9).
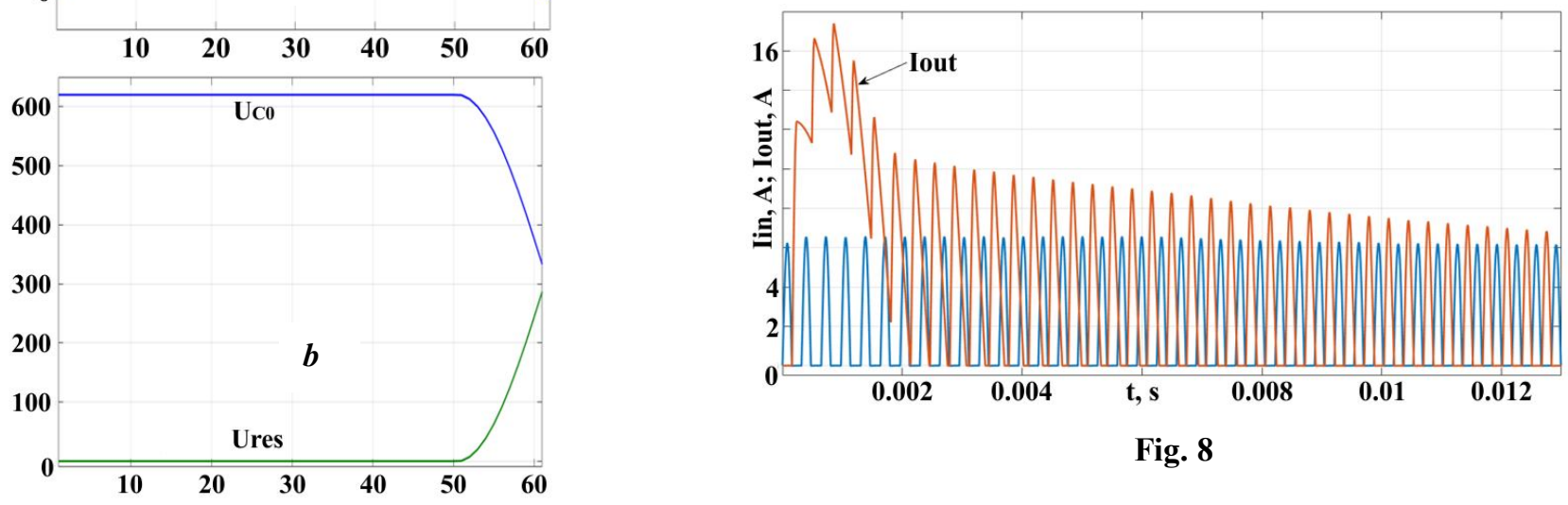

Fig. 8

Fig. 7
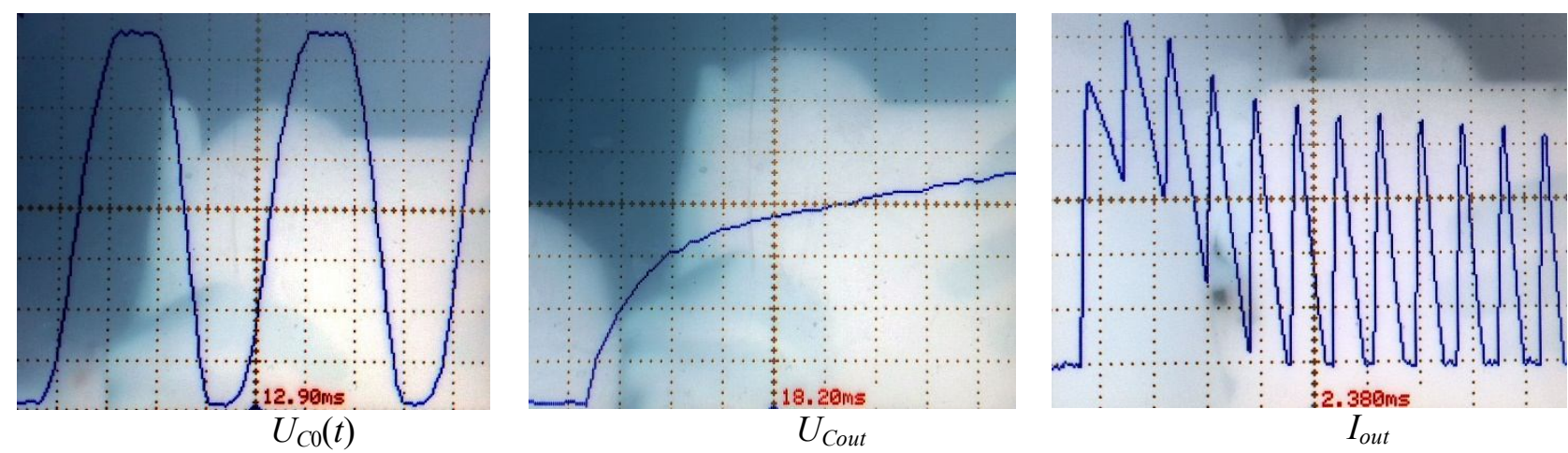

Fig. 9

\section{Conclusion.}

The proposed converter schematic with the intermediate dosing capacitor has notable advantages as compared with the classical approaches, namely - low dynamical energy losses and algorithmic flexibility. If the charging time isn't the major parameter than the physical implementation of the converter, e.g. with an additional diode, does not require complex feed-backs and tracking systems. The system doesn't tend to malefaction from external electromagnetic interferences due to its inbuilt properties, which induce overvoltages and overcurrents. After more detailed analysis of the system energy efficiency behavior, first of all with considering the reactors quality factor, we'll cover the system possible practical applications. 
1. Demirchyan K., Neyman L. Theoretical Foundations of Electrical Engineering. Vol. 2. - SPb.: Piter, 2006. 576 p. (Rus)

2. Milyakh A.N., Volkov I.V. Stabilized current systems based on inductive-capacitive converters. - Kiev: Naukova Dumka, 1974. - 216 p. (Rus)

3. Pentegov I.V. Fundamentals of the charging circuits theory for capacitive energy storage devices. - Kiev: Naukova Dumka, 1982. -420 p. (Rus)

4. Polishchuk Yu.A. To the study of charging systems of capacitive storage devices from a source of limited power / Ustroistva preobrazovatelnoi tekhniki, vypusk 1. - Kiev: Naukova Dumka, 1969. - Pp. 10-16. (Rus)

5. Rashid M.H. Power Electronics Handbook. - N.-Y.: Academic Press, 2002. -895 p.

6. Shcherba A.A., Suprunovska N.I. Electric energy loss at energy exchange between capacitors as function of their initial voltages and capacitances ratio // Tekhnichna Elektrodynamika. -2016. - No 3. - Pp. 9-11.

\section{УДК 621.314}

\section{КЕРОВАНИЙ ПЕРЕТВОРЮВАЧ РЕЗОНАНСНОГО ТИПУ ДЛЯ ЄМНІСНИХ}

\section{ЕЛЕКТРОРОЗРЯДНИХ НАВАНТАЖЕНЬ}

І.В. Волков, чл.-кор. НАН України, С.В. Подольний, канд.техн.наук Інститут електродинаміки НАН України, пр. Перемоги, 56, Київ, 03057, Україна,

e-mail: dgp@ukr.net

Розроблено декілька способів керування вибраною структурою резонансного перетворювача, щяо працює на ємнісне електроразрядне навантаження. Деякі методи розглянуто детально, один із них - з практичною перевіркою. Така система має дві основні переваги: повний/частковий режим софт-світчінгу, який дозволяє використовувати іï на більш високих частотах без суттєвого зниження ККД; керована передача енергії без суттєвих ускладнень силової частини/системи керування. Бібл. 6, рис. 9.

Ключові слова: резонансний перетворювач, ємнісне електророзрядне навантаження, софт-світчінг.

1. Демирчян К., Нейман Л. Теоретические основы электротехники. Т.2. - СПб.: Питер, 2006. - 576 с.

2. Милях А.Н., Волков И.В. Системы стабилизированного тока на основе индуктивно-емкостных преобразователей. - Киев: Наукова думка, 1974. - 216 с.

3. Пентегов И.В. Основы теории зарядных цепей емкостных накопителей энергии. - Киев: Наукова думка, 1982. $-420 \mathrm{c}$.

4. Полищук Ю.А. К исследованию систем заряда емкостных накопителей от источника ограниченной мощности / Устройства преобразовательной техники, вып. 1. - Киев: Наукова думка, 1969. - С. 10-16.

5. Rashid M.H. Power Electronics Handbook. - N.-Y.: Academic Press, 2002. - 895 p.

6. Shcherba A.A., Suprunovska N.I. Electric energy loss at energy exchange between capacitors as function of their initial voltages and capacitances ratio // Технічна електродинаміка. - 2016. - № 3. - С. 9-11.

\section{УДК 621.314}

УПРАВЛЯЕМЫЙ ПРЕОБРАЗОВАТЕЛЬ РЕЗОНАНСНОГО ТИПА ДЛЯ ЕМКОСТНЫХ ЭЛЕКТРОРАЗРЯДНЫХ НАГРУЗОК

И.В. Волков. чЛ.-корр. НАН Украины, С.В. Подольный, канд.техн.наук

Институт электродинамики НАН Украины, пр. Победы, 56, Киев, 03057, Украина, e-mail: $\underline{\text { dgp@ukr.net }}$

Разработан ряд способов управления выбранной структурой резонансного преобразователя, работающего на емкостную электроразрядную нагрузку. Некоторые методы рассмотрены детально, один из них - с практической проверкой. Данная система обладает двумя основными преимуществами: полный/частичный режим софт-свитчинга, что позволяет использовать её на более высоких частотах без существенного снижения КПД; управляемая передача энергии без существенных усложнений силовой части/системы управления.

Библ. 6, рис. 9.

Ключевые слова: резонансный преобразователь, емкостная электроразрядная нагрузка, софт-свитчинг. 